\title{
Stomatopod Crustacea from the Dampier Archipelago, Western Australia
}

\author{
Shane T. Ahyong \\ Marine Biodiversity and Biosecurity, NIWA, Private Bag 14901, Kilbirnie, \\ Wellington, New Zealand. \\ email: s.ahyong@niwa.co.nz
}

\begin{abstract}
The stomatopod Crustacea collected principally from the Dampier Archipelago, containing 14 species from four families and nine genera, are reported. Seven species are newly recorded from the Dampier Archipelago and two species, Gonodactylellus dianae and Acanthosquilla melissae, are described as new. Anchisquilla subfasciata (Tate, 1883), previously regarded as a synonym of Anchisquilla fasciata (de Haan, 1844), is removed from synonymy and recognised for all Australian records previously attributed to the latter species.
\end{abstract}

\section{INTRODUCTION}

Recent expeditions to the Dampier Archipelago in 1998 and 1999, coordinated by the Western Australian Museum, resulted in the present collection of shallow water Stomatopoda. Although the Australian Stomatopoda was recently revised (Ahyong, 2001), including material from northwestern Australia, the fauna of the Dampier Archipelago has not been specifically studied. The present series includes 14 species, divided among four families and nine genera. Two new species are described and a third is removed from synonymy.

\section{MATERIALS AND METHODS}

Terminology and size descriptors follow Ahyong (2001). Abbreviations: antennule (A1); antenna (A2); abdominal somite (AS); thoracic somite (TS); juvenile (juv.), station (stn). All measurements are in millimetres $(\mathrm{mm})$. Unless otherwise indicated, measurements given for specimens indicate total length (TL), measured along the midline from the tip of the rostrum to the apices of the submedian teeth. Carapace length $(C L)$ is measured along the midline and excludes the rostral plate. Corneal index $(\mathrm{CI})$ is given as $100 \mathrm{CL} /$ cornea width. Synonymies are restricted to regional, primary and major works. Propodal index (PI) is given as $100 \mathrm{CL} /$ propodus length. The abdominal-width carapacelength index (AWCLI) is given as 1000 times width of AS5 divided by carapace length. Specimens are deposited in the collections of the Australian Museum, Sydney (AM), the National Natuurhistorisch Museum, Leiden (NNM), the Northern Territory Museum of Arts and Sciences, Darwin (NTM), the South Australian Museum (SAM) and the Western Australian Museum, Perth (WAM).

\section{SYSTEMATICS}

\section{Family Gonodactylidae Giesbrecht, 1910}

Gonodactylaceus falcatus (Forskål, 1775)

Cancer falcatus Forskäl, 1775: 96 [type locality: Djeddah, Red Sea, by neotype selection (Manning and Lewinsohn, 1981)].

Gonodactylus graphurus. - White, 1847: 85 [part, not G. graphurus Miers, 1875].

Gonodactylus chiragara var. mutatus Lanchester, 1903: 450 [type locality: Furnadu Velu, Miladummadulu Atoll, Maldive Is, $6^{\circ} 00^{\prime} \mathrm{N}$, $\left.73^{\circ} 10^{\prime} \mathrm{E}\right]$.

Gonodactylus glaber var. rotundus Borradaile, 1907: 211-212, pl. 22: fig. 2 [type locality: Coetivy, Seychelle Is, $7^{\circ} 08^{\prime} \mathrm{S}, 56^{\circ} 16^{\prime} \mathrm{E}$, and Zanzibar, $\left.6^{\circ} 10^{\prime} \mathrm{S}, 39^{\circ} 12^{\prime} \mathrm{E}\right]$.

Gonodactylus glabrous. - McNeill, 1926: 316-317; Hale, 1929a: 33; Hale, 1929b: 67 [not G. glabrous Brooks, 1886]

Gonodactylus falcatus. - Stephenson, 1952: 11, Stephenson, 12; 1953: 47; Stephenson and McNeill, 1955: 249-250, Stephenson, 1962: 34; McNeill, 1968: 89.

Gonodactylus aloha Manning and Reaka, 1981a: 190-200, figs. 1-3 [type locality: Oahu, Hawaiian [s].

Gonodactylus siamensis Manning and Reaka, 1981b: 479-482, fig. 1 [type locality: Sattahip, Gulf of Thailand, $\left.12^{\circ} 40^{\prime} \mathrm{N}, 100^{\circ} 52^{\prime} \mathrm{E}\right]$.

Gonodactylus insularis Manning and Reaka, 1982: 347-351, figs. 1, 2 [type locality: Kidrenen I., Enewetak, $11^{\circ} 22^{\prime} 50^{\prime \prime} \mathrm{N}, 162^{\circ} 10^{\prime} 30^{\prime \prime} \mathrm{E}$. 
Gonodactylus takedai Moosa, 1989: 227, fig. 1 [type locality: Miyanohama, Chichi-jima, Ogasawara Is].

Gonodactylaceus gravieri Manning, 1995: 42, 43, 46-48, fig. 13 [type locality: Poulo Condore, Vietnam].

Gonodactylaceus falcatus. - Ahyong and Norrington, 1997: 98-99; Ahyong, 2001: 35-38, fig. 17; Ahyong and Davie, 2002: 43.

\section{Material examined}

Western Australia, Dampier Archipelago. WAM C 27592 (1 juv. male, $12 \mathrm{~mm}$ ), stn DA3/99/38, Malus I. $\left(20^{\circ} 30.63^{\prime} \mathrm{S}, 116^{\circ} 38.79^{\prime} \mathrm{E}\right)$, intertidal, 27.08.1999; WAM C 27595 (2 females, 39-40 mm), stn DA3/99/ 45, Rosemary I. (20²9.67'S, $\left.116^{\circ} 35.59^{\prime} \mathrm{E}\right), 30.08 .1999$; WAM C 27596 (1 male, 32 mm), stn DA3/99/45, Rosemary I. $\left(20^{\circ} 29.67^{\prime} \mathrm{S}, 116^{\circ} 35.59^{\prime} \mathrm{E}\right), 30.08 .1999$; WAM C 27590 (1 female, $35 \mathrm{~mm}$ ), stn DA3/99/42, Georgeff Reefs $\left(20^{\circ} 20.34^{\prime} S, 116^{\circ} 36.80^{\prime} \mathrm{E}\right), 28.08 .1999$; WAM C 25682 (1 female, $37 \mathrm{~mm}$ ), stn DA1/98/34, Tozer I. $\left(20^{\circ} 27.684^{\prime} \mathrm{S}, 116^{\circ} 50.486^{\circ} \mathrm{E}\right)$, intertidal sand flat backed by mangroves, 29.10.1998; WAM C 25845 (1 male, $23 \mathrm{~mm}$ ), stn DA1/98/29, Legendre I. $\left(20^{\circ} 24.566^{\prime} \mathrm{S}, 116^{\circ} 53.714^{\prime} \mathrm{E}\right), 4.5 \mathrm{~m}$, among coral sponge and brown algae, 27.10.1998; WAM C 25427 (1 male, $26 \mathrm{~mm}$ ), stn DA1/98/01, Dolphin 1. (2025.852'S, $\left.116^{\circ} 52.953^{\prime} \mathrm{E}\right)$, muddy sand, live coral and coral rubble on gentle slope, 17.10.1998; WAM C 25902 (1 juv. male, $12 \mathrm{~mm}$ ), stn DA1/98/35, Legendre I. $\left(20^{\circ} 23.620^{\prime} \mathrm{S}, 116^{\circ} 51.960^{\prime} \mathrm{E}\right)$, shallow subtidal, among small coral bommies (faviids), some sponges, no Acropora, 29.10.1998.

\section{Remarks}

In the adult specimens, the median carinule on AS6 is present but low. Gonodactylaceus falcatus was reported from northwestern Australia by Ahyong (2001), although the present records are the first for the Dampier Archipelago.

\section{Distribution}

Widely distributed in the Indo-West Pacific, from the Red Sea to Australia, New Caledonia, Indonesia, the South China Sea to Japan and Hawaii (Ahyong, 2001).

\section{Gonodactylaceus graphurus (Miers, 1875)}

Gonodactylus graphurus White, 1847: 85 [nomen nudum].

Gonodactylus graphurus Miers, 1875: 344 [part, White's material only; type locality: Torres Str., Qld, Australia, by lectotype designation (Ingle, 1971)]. - Kemp, 1913: 169-170.-Balss, 1921: 5.-Alexander, 1916: 9.-Stephenson, 1952: 12; 1953a: 47.-Stephenson \& McNeill, 1955: 250.Stephenson, 1962: 35.-Manning, 1966: 108-109.
Gonodactvlaceus graphurus.-Manning, 1995: 19, 42-43. - Ahyong and Norrington, 1997: 99100.-Ahyong, 2001: 40-42, fig. 19.-Ahyong and Davie, 2002: 44.

\section{Material examined}

Western Australia: WAM C 25776 (1 female, 47 $\mathrm{mm}$ ), Cleaverville, 05.08.2000; WAM C 25775 (1 female, $14 \mathrm{~mm}), 1.1 \mathrm{n}$. mls $\mathrm{W}$ of Bluff Pt, Enderby I. (20 $\left.20^{\circ} .37^{\prime} \mathrm{S}, 116^{\circ} 31.69^{\prime} \mathrm{E}\right), 20.07 .1999$; WAM C 27180 (1 female, $38 \mathrm{~mm}$ ), Tish Pt, Rosemary I. $\left(20^{\circ} 30.48^{\prime} \mathrm{S}\right.$, $116^{\circ} 36.53^{\prime} \mathrm{E}$ ), 26.07.1999; WAM C 25773 (1 female, $34 \mathrm{~mm})$, Angel I. (20²7.965'S, $\left.116^{\circ} 49.692^{\prime} \mathrm{E}\right), 8.5 \mathrm{~m}$, many sponges and soft corals on pavement with some coarse shelly sediment, some hard corals (faviids and Turbinaria), 29.10.1998; WAM C 27153 ( 1 male, $30 \mathrm{~mm}$; 1 female, $22 \mathrm{~mm}$ ), Bluff Pt, Enderby I. $\left(20^{\circ} 37.05^{\prime} \mathrm{S}, 116^{\circ} 33.86^{\prime} \mathrm{E}\right), 19.07 .1999 ;$ WAM C 27147 ( 2 males $27-38 \mathrm{~mm}$ ), Hugg I. $\left(20^{\circ} 26.52^{\prime} \mathrm{S}\right.$, $117^{\circ} 00.50^{\prime} \mathrm{E}$ ), 16.07.1999; WAM C 27600 (1 male), stn DA3/99/33, Nelson Rocks (20²7.99'S, 116 39.71'E), 07.09.1999; WAM C 27597 (1 female, $39 \mathrm{~mm}$ ), stn DA3/99/19, Enderby I. $\left(20^{\circ} 36.22^{\prime} S, 116^{\circ} 33.63^{\prime} \mathrm{E}\right)$, 02.09.1999; WAM C 27184 (2 males, $30-43 \mathrm{~mm} ; 2$ females, 36-39 mm), stn DA2/99/95, Bluff Pt, Enderby I. (20 $\left.37.37^{\prime} \mathrm{S}, 116^{\circ} 31.69^{\prime} \mathrm{E}\right), 27.07 .1999$; WAM C 27169 (1 male, $37 \mathrm{~mm}$ ), stn DA2/99/72, Rocky Head, Enderby I. (2042.13'S, 116 $\left.{ }^{\circ} 26.22^{\prime} \mathrm{E}\right)$, 24.07.1999; WAM C 27149 (1 female, 78 mm), stn DA2/99/31, Courtenay Head Light, Malus I. $\left(20^{\circ} 29.49^{\prime} \mathrm{S}, 116^{\circ} 40.61^{\prime} \mathrm{E}\right), 18.07 .1999$; WAM C 27163 (1 female, $30 \mathrm{~mm}$ ), stn DA2/99/65, light on East Intercourse I. (20³8.31'S, 116 $\left.{ }^{\circ} 38.46^{\prime} \mathrm{E}\right), 23.07 .1999$; WAM C 27172 ( 1 male, $35 \mathrm{~mm}$; 2 females, $42-44$ $\mathrm{mm})$, NW point on Goodwyn I. $\left(20^{\circ} 32.11^{\prime} \mathrm{S}\right.$, 116 31.55'E), 25.07.1999; WAM C 25774 (2 males, 46-55 mm; 2 females, 44-45 mm), stn DA2/99/84, 2.9 n. mls E of Tish Pt, Rosemary I., (20 29.94'S, 116 38.11'E), 26.07.1999; WAM C 27148 (1 male, 43 mm; 1 female, $43 \mathrm{~mm}$ ), stn DA2/99/14, Sloping Pt., Burrup Pen. $\left(20^{\circ} 35.67^{\prime} \mathrm{S}, 116^{\circ} 54.97^{\prime} \mathrm{E}\right), 16.07 .1999$; WAM C 27164 (1 female, $36 \mathrm{~mm}$ ), stn DA2/99/68, Bluff Pt, Enderby I. (2040.93'S, 116 $\left.33.21^{\prime} \mathrm{E}\right)$, 23.07.1999; WAM C 25623 (1 female, $30 \mathrm{~mm}$ ), stn DA1/98/33, Angel I. (20²7.965'S, 116 49.692'E), 8.5 $\mathrm{m}$, many sponges and soft corals on pavement with some shelly sediment and some hard corals (faviids and Turbinaria), 29.10.1998; WAM C 25777 (2 females, 32-38 mm), stn DA2/99/99, $1.05 \mathrm{n}$. mls WSW of Rocky Head, Enderby I. (20 37.36-37.02'S, $\left.116^{\circ} 26.85-26.44^{\prime} \mathrm{E}\right), 17.0-19.0 \mathrm{~m}$, rake box dredge, rocks and hard corals, gorgonians, hydroids, numerous sponges, 28.07.1999.

\section{Remarks}

Gonodactylaceus graphurus was reported from the Dampier Archipelago by Ahyong (2001). The transverse abdominal grooves, diagnostic for the species, are developed in all specimens. In the 14 
$\mathrm{mm}$ female (WAM C 25775), the anterolateral comers of the rostral plate are rounded instead of angular, and the median carinule on AS6 is undeveloped instead of distinct, features related to its small size.

\section{Distribution}

Tropical Australia, Southern Indonesia and New Hebrides (Ahyong, 2001).

\section{Gonodactylellus affinis (de Man, 1902)}

Gonodactylus chiragra var. affinis de Man, 1902 912 type locality: Ternate, Molucca Is, Indonesia, $0^{\circ} 48^{\prime} \mathrm{N}, 127^{\circ} 20^{\prime} \mathrm{E}$ ].

Gonodactylus chiragra var. confinis de Man, 1902 : 912, pl. 27, fig. 66 [type locality: Ternate, Molucca Is, Indonesia, $\left.0^{\circ} 48^{\prime} \mathrm{N}, 127^{\circ} 20^{\prime} \mathrm{E}\right]$.

Gonodactylus chiragra var. segregatus Lanchester, 1903: 448, pl. 23, figs. 6, 7 [type locality: Minikoi Laccadive Is, restricted by lectotype designation (Ahyong, 2001)].

Gonodactylellus affinis.-Ahyong, 2001: 46-48, fig. 21. - Ahyong and Davie, 2002: 46-47.

\section{Material examined}

Western Australia, Dampier Archipelago. WAM C 27139 (1 male, $21 \mathrm{~mm}$; female, $27 \mathrm{~mm}$ ), stn DA2/ 99/04, Cohen I. (20'19.64'S, 116 $\left.45.75^{\prime} \mathrm{E}\right), 14.07 .1999$; WAM C 27158 ( 2 juv. females, 9 mm), stn DA2/99/ 50, Rocky Head, Enderby I. (2037.10'S, 11620.99'E), dredge, 20.07.1999; WAM ex C 27594 (1 female, 24 $\mathrm{mm})$, stn DA3/99/53, Enderby I. (20\%34.53's, $\left.116^{\circ} 34.58^{\prime} \mathrm{E}\right)$, from rock, 01.01.1999; WAM C 25783 (1 male, $23 \mathrm{~mm}$ ), stn DA2/99/84, $2.9 \mathrm{n}$. mls E of Tish Pt. (20029.94'S, 116 38.11'E), 26.07.1999; WAM C 25782 (1 male, $22 \mathrm{~mm}$; female, $23 \mathrm{~mm}$ ), stn DA2/ $99 / 13,-2.25$ n. mls E of Haüy I. $\left(20^{\circ} 26.52^{\prime} \mathrm{S}\right.$, $117^{\circ} 00.50^{\prime} \mathrm{E}$ ), 16.07.1999; WAM C 25779 (1 female, $20 \mathrm{~mm})$, stn DA2/99/10, NE corner of Delambre 1 . $\left(20^{\circ} 23.97^{\prime} \mathrm{S}, 116^{\circ} 04.82^{\prime} \mathrm{E}\right), 15.07 .1999$; WAM C 27159 (1 female, $13 \mathrm{~mm}$ ), stn DA2/99/51, SW point of Goodwyn I. $\left(20^{\circ} 32.40^{\prime} \mathrm{S}, 116^{\circ} 24.19^{\prime} \mathrm{E}\right), 21.07 .1999$; WAM C 25780 (1 male, $22 \mathrm{~mm}$ ), stn DA2/99/33 $\left(20^{\circ} 27.41^{\prime} \mathrm{S}, 116^{\circ} 42.57^{\prime} \mathrm{E}\right), 18.07 .1999 ;$ WAM ex C 27178 (1 male, $10 \mathrm{~mm}$ ), W point of Brigadier I., stn DA2/99/88, (2026.04'S, $\left.11636.77^{\prime} \mathrm{E}\right), 26.07 .1999$; WAM C 25624 (1 broken female), stn DA1/98/33, Angel I. $\left(20^{\circ} 27.965^{\prime} \mathrm{S}, 116^{\circ} 49.692^{\prime} \mathrm{E}\right), 8.5 \mathrm{~m}$, many sponges and soft corals on pavement with some shelly sediment and some hard corals (faviids and Turbinaria), 29.10.1998; WAM C 27179 (1 temale, 9 $\mathrm{mm})$, stn DA2/99/91, Tish Pt, Rosemary I. (2030.48'S, 116 36.53'E), dredge, 26.07.1999; WAM C 25781 ( 2 males, $24 \mathrm{~mm}$; 3 females; $21-23 \mathrm{~mm}$ ), stn DA2/99/76, NW point of Goodwyn I. (2032.11'S, $11631.55 \mathrm{E}$ ), 25.07.1999; WAM C 27144 (1 female,
$11 \mathrm{~mm}$ ), NE corner of Delambre I., stn DA2/99/09 (2020.38' $\left.117^{\circ} 05.22 \mathrm{E}\right)$, dredge, 15.07.1999; WAM C 27141 (1 male, $21 \mathrm{~mm}$; female, $28 \mathrm{~mm}$ ), stn DA2 99/06, C. Legendre $\left(2021.69^{\prime} \mathrm{S}, 11652.40^{\prime} \mathrm{E}\right)$, 14.07.1999; WAM C 27146 (1 male, 21 mm), stn DA2/99/10, NE corner of Delambre I. (20 23.97'S, 11704.82'E), dredge, 15.07.1999; WAM C 27173 (1 female, $27 \mathrm{~mm})$, stn DA2/99/76. NW point of Goodwyn I. (2032.11'S, 116 31.55'E), 25.07.1999; WAM C 27160 (1 female, $11 \mathrm{~mm}$ ), stn DA2/99/57, Roly Rock (20²9.03'S, 116 30.45'E), 21.07.1999.

\section{Remarks}

Ahyong (2001) reported $G$, affinis from the Dampier region. In the present series, sexual dimorphism in the degree of telson inflation resembles that reported by Moosa and Cleva (1984a) and Ahyong (2001). The posterior spine on the median carina of the telson is present on all individuals, though the posterior spine on the accessory median and anterior submedian carinae is present only in specimens exceeding $10 \mathrm{~mm}$ TL An incipient granule is usually evident on the posterior margin of the accessory median carinae of specimens of $10 \mathrm{~mm}$ TL or smaller. In several adult specimens, the posterior spines on the accessory median and anterior submedian carinae are indicated by a shallow pit, having probably been damaged in agonistic encounters.

\section{Distribution}

Western Pacific Ocean to the Philippines, Macclesfield Bank, South China Sea, Vietnam, Thailand, Indonesia and Australia (Ahyong, 2001).

\section{Gonodactylellus rubriguttatus Erdmann and Manning, 1998}

Gonodactylellus rubriguttatus Erdmann and Manning, 1998: 619-620, fig. 1d [type locality: Tanjung Torosie, Komodo/Rinca, Indonesial.Ahyong, 2001: 60-61, fig. 29.- Ahyong and Davie, 2002: 46

\section{Material examined}

Western Australia, Dampier Archipelago. WAM C 27591 (1 male, $11 \mathrm{~mm}$ ), stn DA3/99/21, Eaglehawk I. $\left(20^{\circ} 38.98^{\prime} \mathrm{S}, 116^{\circ} 26.21 \mathrm{E}\right), 2.0-3.0 \mathrm{~m}, 03.09 .1999$.

\section{Remarks}

Gonodactylellus rubrigutatus was reported from northwestern Australia, as far south as the Abrolhos Islands (Ahyong, 2001). The petasma is well developed in the single specimen examined.

\section{Distribution}

Indonesia, Australia, and New Caledonia (Ahyong, 2001). 
Gonodactylellus dianae sp. nov. Figure 1

Gonodactylellus snidsvongi.-Ahyong, 2001: 61-63, fig. 30.- Ahyong and Davie, 2002: 46 [misspelling; Australian specimen, not $G$. snidvongsi (Naiyanetr, 1987)].

\section{Material examined}

\section{Holotype}

Western Australia, Dampier Archipelago. WAM C 27599 (male, $19 \mathrm{~mm}$ ), stn DA3 (precise station uncertain).

\section{Paratypes}

Western Australia. WAM C 25414 (1 female, 9 $\mathrm{mm})$, stn DA1/98/06, Haüy I. $\left(20^{\circ} 25.725^{\prime} \mathrm{S}\right.$, $116^{\circ} 57.580^{\prime} \mathrm{E}$ ), low relief limestone pavement with shallow sandy gullies, few loose rocks, very little coral cover, very silty, 19.10.1998; WAM C 25620 (2 juv. males, 10-12 mm), stn DA1/98/09, Angel I. $\left(20^{\circ} 28.692^{\prime} \mathrm{S}, 116^{\circ} 47.950^{\prime} \mathrm{E}\right), 2-3 \mathrm{~m}$, limestone platform with sand cover and protruding pavement, scattered flat rocks, patchy algal growth, strong current and surge, 20.10.1998; WAM C 29365 (1 juv. male, $8 \mathrm{~mm}$ ), stn DA1/98/09, Angel I. (20²8.692'S, $\left.116^{\circ} 47.950^{\prime} \mathrm{E}\right), 2-3 \mathrm{~m}, 20.10 .1998$; NTM (1 male, $11 \mathrm{~mm}$ ), Pt Samson (20³8'S, 117 $\left.11^{\circ} \mathrm{E}\right)$, shore reef, 09.02.1988.

\section{Diagnosis}

Ocular scales low, fused, anterior margin transverse. Rostral plate with transverse or slightly concave anterior margins; anterolateral corners angular; lateral margins divergent anteriorly; median spine longer than base. Mandibular palp 2segmented. Raptorial claw dactylus with proximal notch. AS6 with posterolateral spine. Telson with spiniform submedian denticles; intermediate teeth slender, elongate, apices extending posteriorly well beyond mid length of submedian teeth; lateral teeth sharp, projecting well off margin of telson. Telson median carina and accessory median carinae, together with a group of 6 posterior spines ( 2 spines on median, lower longest; 2 spines on each accessory median); anterior submedian carina terminating in 2 distal conical spines; submedian tooth with 2 large dorsal spines in transverse row, outer spine conical, longer than half length of tooth; intermediate carina with large, conical dorsal spine, longer than half length of tooth; submedian and intermediate teeth with ventral carina. Uropodal exopod proximal margin with non-setose inner margin; distal margin with ventral spine. Exopod distal segment with setose outer margin and smooth, non-setose inner margin. Uropodal endopod length 2.48-2.87 breadth; distal half of outer margin setose, remainder smooth, nonsetose.

\section{Description}

Eyes elongate; cornea subconical. Ocular scales low, fused, anterior margin transverse. A1 peduncle length $0.61-0.68 \mathrm{CL}$. Dorsal and ventral distal teeth of A2 protopod with acute apices; scale length 0.38 $0.44 \mathrm{CL}$. Rostral plate as long as or slightly longer than broad; basal portion with transverse or slightly concave anterior margins; anterolateral corners angular except in juveniles $10 \mathrm{~mm}$ TL or smaller; lateral margins divergent anteriorly; median spine longer than base, laterally flattened, with obtusely angular ventral keel. Raptorial claw dactylus with proximal notch; propodus with proximal movable spine, opposable margin sparsely pectinate proximally. Mandibular palp 2-segmented. Maxillipeds 1-5 with epipod. TS6-7 lateral processes subequal to or slightly broader than that of TS6; lower margins subtruncate. TS8 anterolateral margin rounded; sternal keel obsolete. Pleopod 1 endopod with lateral lobe on posterior endite. AS1-5 posterolateral angles unarmed. AWCLI 792-846. Submedian, intermediate and lateral bosses of AS6 with posterior spine. Telson slightly broader than long; with 10-14 spiniform submedian denticles; intermediate teeth slender, elongate, apices extending posteriorly well beyond midlength of submedian teeth; lateral teeth with sharp apex, projecting well off margin of telson, indicated by a wide, V-shaped notch. Telson median carina tumid in males, but not obscuring accessory median carinae, together with a group of 6 posterior spines in adults ( 2 spines on median, lower longest; 2 spines on each accessory median); anterior submedian carina flanked by low rounded carina and terminating in 2 distal conical spines, upper largest; submedian tooth with 2 large, conical, dorsal spines in transverse row, outer spine longer than half length of tooth; intermediate tooth with large, conical, dorsal spine, longer than half length of tooth; knob absent; submedian and intermediate teeth with ventral carina. Uropodal protopod terminal spines with length subequal; upper proximal surface with obtuse swelling behind dorsal carina. Uropodal exopod proximal segment outer margin with 9-11 (usually 10) movable spines, distal-most slightly exceeding apex of distal segment; inner margin smooth, non-setose; distal margin with ventral spine; exopod distal segment with outer margin setose, inner margin smooth, non-setose. Uropodal endopod length $2.48-2.87$ breadth; distal half of outer margin setose, remainder smooth, non-setose.

\section{Colour in alcohol}

Faded to dull green; with scattered black spots on median surface of TS6, AS1, 4 and 5.

\section{Measurements of the holotype}

TL $19 \mathrm{~mm}$, CL $3.60 \mathrm{~mm}, \mathrm{~A} 1$ peduncle length 2.30 $\mathrm{mm}$, A2 scale length $1.50 \mathrm{~mm}$, AS5 width $2.85 \mathrm{~mm}$. 


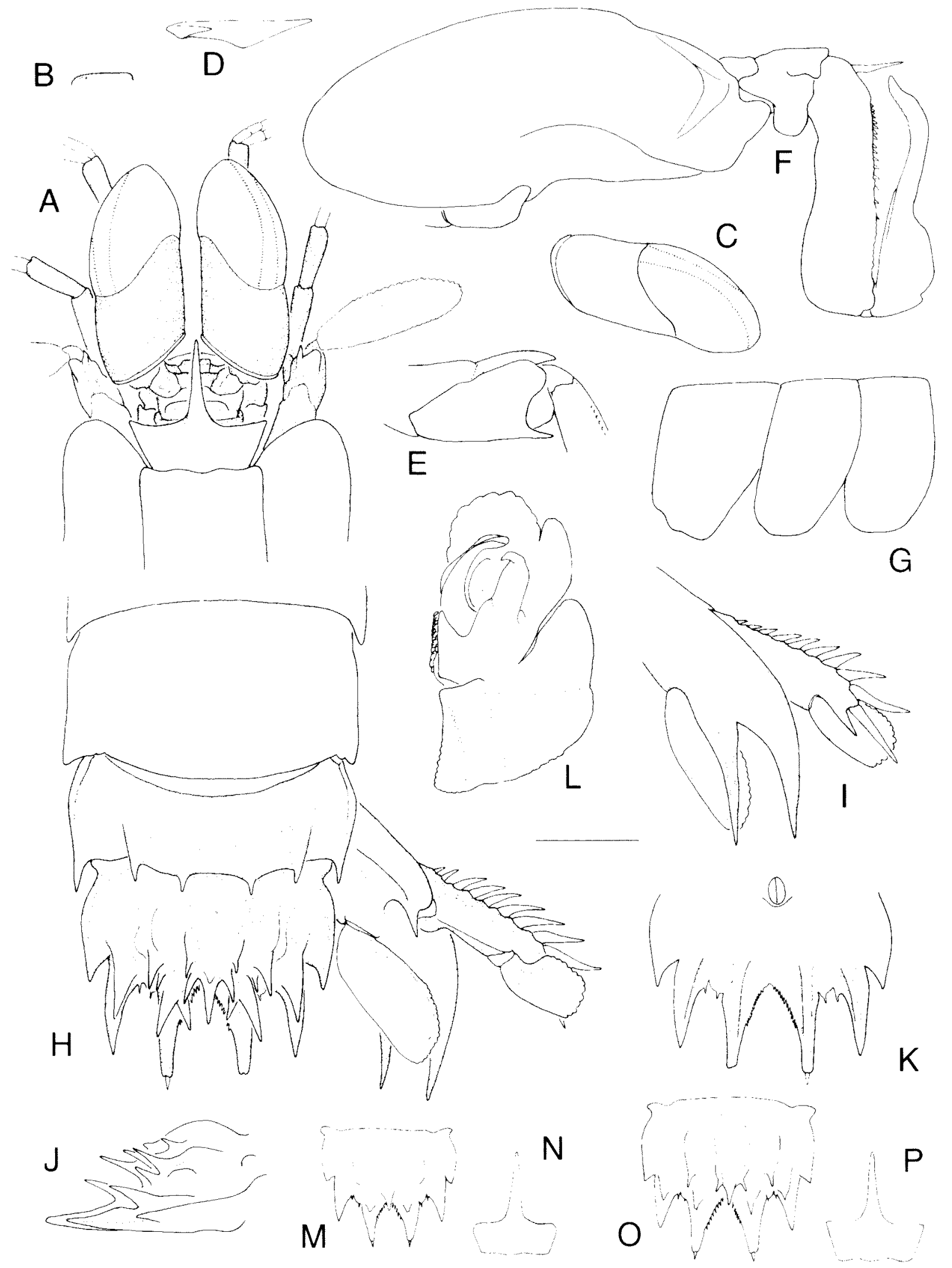

Figure 1 Gonodactylellus dianae sp. nov., Dampier Archipelago. A-L, male holotype TL 19 mm (WAM C 27599); M, N, male paratype TL $10 \mathrm{~mm}$ (WAM C 25620); O, P, male paratype TL $12 \mathrm{~mm}$ (WAM C 25620). A, anterior; $\mathbf{B}$, ocular scales, C, eyes, right lateral view; D, rostral plate, right lateral view; E, right A2 protopod; F, right raptorial claw, lateral view; $\mathbf{G}$, TS6-8, right lateral view; H, AS5, 6, telson and uropod; $\mathbf{I}$, left uropod, ventral view; $\mathbf{J}$, telson, right lateral view; $\mathbf{K}$, telson, ventral view; $\mathbf{L}$, right pleopod endopod, anterior view; $\mathbf{M}, \mathbf{O}$, telson; N, P, rostral plate. Scale A-D, F-K, M-P = $1.0 \mathrm{~mm}$. E, $\mathrm{L}=0.5 \mathrm{~mm}$. 


\section{Etymology}

Named for Diana Jones, Western Australian Museum, for her central role in coordinating the study of the Dampier marine fauna.

\section{Remarks}

Gonodactylellus dianae sp. nov. (Figure 1) most closely resembles $G$. snidvongsi (Naiyanetr, 1987) (Figure 2, type locality: Ko Kangkao, Chonburi Province, Thailand) differing in subtle aspects of the ocular scales, telson shape and spination. The ocular scales in adult Gonodactylellus dianae are fused medially with a transverse margin, whereas in $G$. snidvongsi, the ocular scales, whilst low, are separated by a shallow but distinct emargination. The telson of $G$. dianae has a less triangular general outline than $G$. snidvongsi owing to the proportionally more elongate and more slender primary teeth (compare Figures $1 \mathrm{H}, \mathrm{K}$ and Figure 2C). Notably, the apices of the lateral teeth on the telson of $G$. dianae reach posteriorly to a level slightly beyond the base of the sinus between the submedian teeth. In contrast, the apices of the lateral teeth in G. snidvongsi fall distinctly short of the sinus between the submedian teeth. The most obvious differences between adult $G$. dianae and $G$. snidvongsi, however, are in overall telson spination, in which the dorsal spines are larger but fewer in number in the new species. In $G$. dianae the submedian primary teeth of the telson bear two proximal dorsal teeth, of which the outer exceeds half the length of the submedian tooth. In $G$. snidvongsi of $16 \mathrm{~mm}$ or larger, a cluster of occasionally two, but usually three or more spines is present at the base of each submedian primary tooth; none of the dorsal spines approach half the length of the submedian primary teeth. Similarly, the single dorsal spine on the anterior intermediate carina in $G$. dianae exceeds half the length of the intermediate primary tooth. In G. snidvongsi of 16 $\mathrm{mm}$ or larger, however, two or more spines are present on the intermediate primary teeth and none approach half the length of the intermediate tooth.

The telson and rostral plate of the $10 \mathrm{~mm}$ and 12 mm paratypes (WAM C 25620) are shown in Figure $1 \mathrm{M}-\mathrm{P}$. At $10 \mathrm{~mm}$, the corners of the rostral plate are rounded and telson spination is rudimentary, with only the posterior spine on the median carina and dorsal spine on each submedian tooth developed. By $12 \mathrm{~mm}$, the rostral corners are angular as in adults, the intermediate primary teeth also bear a dorsal spine, and the anterior submedian and accessory median carinae are posteriorly armed. In the juvenile specimens, telson spination is not fully developed and the intermediate primary telson teeth have not reached full length. The telson outline in juvenile $G$. dianae resembles that of $G$. snidvongsi. As such, small specimens of $G$. dianae could presumably be confused with similarly size G. snidvongsi as with the $11 \mathrm{~mm}$ specimen reported by Ahyong (2001) as the latter. Unfortunately, juvenile $G$. snidvongsi are yet to be studied. Owing to the differences in telson spination between adults of $G$. snidvongsi and $G$. dianae, however, differences in juvenile spination will likely be found when small specimens of both species can be compared. It should be noted that the ocular scales in the figure of this $11 \mathrm{~mm}$ specimen (Ahyong, 2001: fig. 30) were incorrectly rendered as separate rather than fused and anteriorly transverse, confirmed by reexamination of the specimen.

Gonodactylellus dianae was collected from shore or near-shore reef habitats to a depth of 2-3 m. Reefs consisted of silted, low relief, limestone pavement or platforms with rubble, rocks and patchy coral or algal cover.

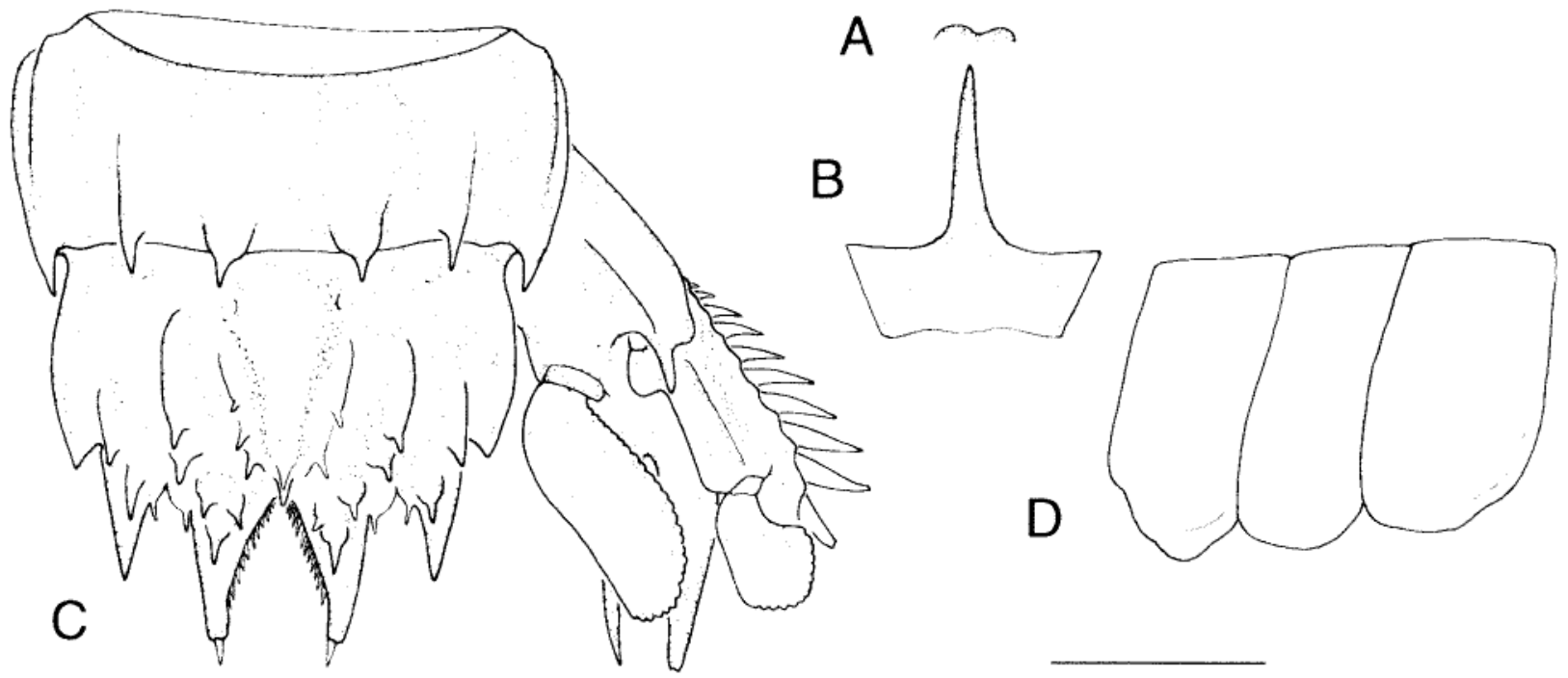

Figure 2 Gonodactylellus snidvongsi (Naiyanetr, 1987). NNM S1041, female holotype TL 16 mm, Ko Kangkao, Chonburi Province, Thailand. A, ocular scales; B, rostral plate; C, AS6, telson and uropod; D, TS6-8, right lateral. Scale $=1.0 \mathrm{~mm}$. 


\section{Distribution}

Presently known only from the Dampier Archipelago.

\section{Gonodactylus chiragra (Fabricius, 1781)}

Squilla chiragra Fabricius, 1781: 515 [type locality: restricted to Ambon, Indonesia, $3^{\circ} 43^{\prime} \mathrm{S}, 1281 \mathrm{~S}^{\prime} \mathrm{E}$, by neotype selection (Manning, 1981: 217)].

Gonodactylus chiragra.- White, 1847: 84. - Kemp, 1913: 4, 11, 147, 155, fig. 2, pl. 9, fig. 107 [part].McNeill, 1926: 316 [part].-Hale, 1929a: 34.Stephenson, 1952: 11. - Stephenson and MCNeill, 1955: 250-252 [part]. - Stephenson, 1962: 34.Manning, 1966: 108, 113-114 (part).-MoNeill, 1968: 89.-Ahyong and Norrington, 1997: 100101.-Ahyong, 2001: 67-70, fig. 34.-Ahyong and Davie, 2002: 42, 47.

\section{Material examined}

Western Australia, Dampier Archipelago. WAM C 25316 (1 female, $31 \mathrm{~mm}$ ), stn DA1/98/14, Unnamed I. (2026.58'S, $\left.116^{\circ} 48.79^{\prime} \mathrm{E}\right), 2-3 \mathrm{~m}$, 20.10.1998; WAM C 25622 ( 1 male, $33 \mathrm{~mm}$ ), Searipple Passage $\left(20^{\circ} 31.230^{\prime} \mathrm{S}, 116^{\circ} 51.182^{\prime} \mathrm{E}\right)$, intertidal, 21.10.1998.

\section{Remarks}

Gonodactylus chiragra was reported from northwestern Australia by Ahyong (2001). The present specimens, however, constitute the first records of $G$. chiragra from Dampier and the southemmost confirmed records from Western Australia. White (1847) listed G. chiragra along with two other tropical species, Haptosquilla trispinosa (Dana, 1852) and a species of the brachyuran decapod Uca (as Gelasimus), from Swan River from the collection of Mr Dring. None of these species have since been reported from the Swan River and H. trispinosa is a Pacific species. As suggested by Ahyong (2001) under the account of H. trispinosa, the Swan River record is almost certainly from northeastern Australia and is perhaps an error for Swan Island, Queensland.

\section{Distribution}

French Polynesia to Japan, Australia, the IndoMalayan region and possibly from the western Indian Ocean.

\section{Gonodactylus smithii Pocock, 1893}

Gonodactylus Smithii Pocock, 1893: 475, pl. 20B [tvpe locality: Arafura Sea].

Gonodactylus chiragra var. anancvrus Borradaile, 1900: 395, 397, 401 Itype localities: Talili Bay, New Britain $\left(4^{\circ} 12^{\circ} \mathrm{S}, 152^{\circ} 08^{\circ} \mathrm{E}\right)$ and Lifu, Loyalty
Is $(2053$ 'S, 167'13'E)].

Gonodactylus chiragra (Fabricius) var. smithii Pocock.-Rathbun, 1914: 664.

Gonodactylus smithii--Manning, 1966: 112-113,Ahyong and Norrington, 1997: 101-102.Ahyong, 2001: 72-75, fig. 36.-Ahyong and Davie, 2002: 48 .

Gonodactylus chiragra. - Stephenson and McNeill, 1955: 250-252 (part, not G. chiragra (Fabricius, 1781)]

Gonodactvlus minikoiensis Ghosh, 1990: 201, 202, fig. 1 type locality: Minikoi, $8^{\circ} 17$ 's, Lakshadweep, $\left.73^{\circ} 02^{\prime} \mathrm{E}\right]$.

Gonodactylus arabica Ghosh, 1990: 201, 205, figs. 2, 3e Itype locality: Kavaratti, Lakshadweep, $\left.10^{\circ} 33^{\circ} \mathrm{N}, 72^{\circ} 38^{\prime} \mathrm{E}\right]$.

\section{Material examined}

Western Australia, Dampier Archipelago. WAM C 25325 (1 male, 8 mm), Legendre I. $\left(20^{\circ} 23.620^{\prime} \mathrm{S}\right.$, $116^{\circ} 51.960^{\prime} \mathrm{E}$ ), shallow subtidal, small faviid coral bommies without Acropora, some sponges, 29.10.1998; WAM C 25396 (1 male, $33 \mathrm{~mm}$ ), stn DA1/98/13, Hamersley Shoal (20²3.203'S, $\left.116^{\circ} 46.691^{\prime} \mathrm{E}\right), 8.5-17 \mathrm{~m}$, from limestone base of Acropora, low relief patchy coral over limestone pavement with shallow layer of sand, shallow gullies, 21.10.1998.

\section{Remarks}

Ahyong (2001) reported G. smithii from the Dampier Archipelago and the present specimens agree well those already reported. In both specimens, the inner margin of the uropodal endopod is convex. As indicated by Ahyong (2005), however, G. smithii as presently understood is heterogeneous and presently subject of further study (in prep.). The $33 \mathrm{~mm}$ male (WAM C 25396) is parasitized on TS8 by the gastropod, Caledoniella.

\section{Distribution}

Reported from South Africa to Australia, the South China Sea, Japan and New Caledonia (Ahyong, 2005).

\section{Protosquillidae Manning, 1980}

\section{Haptosquilla corrugata Ahyong, 2001}

Protosquilla trispinosa-Rathbun, 1914: 663-664, figr. 11 [not $P$. trispinosa (stn na, 1852)].

Gonodactylus pulchellus. - Stephenson, 1962: 35 Inot G. pulchellus Miers, 1880).

Gonodactylus trispinosus.-Alexander, 1916: 9.- 
Balss, 1921: 5.-Stephenson, 1962: 35 [not $G$. trispinosus Dana, 1852].

Haptosquilla corrugata Ahyong, 2001: 102-103, fig. 49 [type locality: off Gantheaume Pt, Broome].Ahyong \& Davie, 2001: 66.

\section{Material examined}

Western Australia, Dampier Archipelago. WAM C 29366 (1 juv. male, 8 mm), stn DA2/99/56, Roly Rock (20³0.10-29.88'S, 116 28.27-27.93'E), 33-34.5 m, 21.07.1999; WAM C 27594 (1 male, $24 \mathrm{~mm}$ ), stn DA3/99/53, Enderby I. (20³4.53'S, 116 $\left.34.58^{\prime} \mathrm{E}\right)$, from rock, 01.09.1999; WAM C 27601 (2 females, 17-20 mm), stn DA3/99/64, West Lewis I. $\left(20^{\circ} 36.66^{\prime} \mathrm{S}, 116^{\circ} 36.96^{\prime} \mathrm{E}\right), 33-34.5 \mathrm{~m}$, from rock, 06.09.1999; WAM C 2714091 juv. male, $12 \mathrm{~mm}$ ), stn DA2/99/06, C. Legendre (20²1.69'S, 116 52.40'E), dredge, 14.07.1999; WAM C 27175 (1 male, 31 mm; 3 females, 27-35 mm), stn DA2/99/84, 2.9 n. mls E of Tish Pt, Rosemary I. (20²9.94'S, 116 38.11'E), 26.07.1999; WAM C 27176 (1 female, $30 \mathrm{~mm}$ ), stn DA2/99/84, $2.9 \mathrm{n}$. mls E of Tish Pt, Rosemary I. (20²9.94'S, 116 38.11'E), 26.07.1999; WAM C 27150 (female, $28 \mathrm{~mm}$ ), stn DA2/99/33, Courtenay Head Light, Malus I. (20²7.41'S, $\left.116^{\circ} 4.57^{\prime} \mathrm{E}\right), 18.07 .1999$; WAM C 27157 (1 female, 16 mm), stn DA2/99/50, Rocky Head, Enderby 1. (20³7.10'S, 116 $\left.20.99^{\circ} \mathrm{E}\right)$, dredge, 20.07.1999; WAM C 27177 (1 male, $30 \mathrm{~mm}$ ), stn DA2/99/85, E point of Brigadier I. $\left(20^{\circ} 26.38^{\prime} \mathrm{S}\right.$, 116 39.76'E), 26.07.1999; WAM C 27152 (1 male, 25 $\mathrm{mm})$, stn DA2/99/96, Bluff Pt, Enderby I. (2037.05'S, 116 $31.56 ' \mathrm{E}$ ), 27.07.1999; WAM C 25618 (1 male,14 $\mathrm{mm}$; 1 female, $15 \mathrm{~mm})$, stn DA1/98/06, Haüy I., Dampier $\left(20^{\circ} 25.725^{\prime} \mathrm{S}, 116^{\circ} 57.580^{\prime} \mathrm{E}\right)$, low relief limestone pavement with shallow sandy gullies, few loose rocks, very little coral cover, very silty, 19.10.1998; WAM C 27186 (1 female, $27 \mathrm{~mm}$ ), stn DA2/99/98, Bluff Pt, Enderby I. $\left(20^{\circ} 39.81^{\prime} \mathrm{S}\right.$, 116 31.92'E), 28.07.1999; WAM C 27155 (1 female, $28 \mathrm{~mm}$ ), stn DA2/99/42, SE point of Goodwyn I. (20³4.16'S, $\left.116^{\circ} 30.11^{\prime} \mathrm{E}\right), 20.07 .1999 ;$ WAM C 27171 ( 2 females, 13-25 mm), stn DA2/99/76, NW point of Goodwyn I. $\left(20^{\circ} 32.11^{\prime} S, 116^{\circ} 31.55^{\prime} \mathrm{E}\right), 25.07 .1999$; WAM C 27187 (1 female, $28 \mathrm{~mm}$ ), stn DA2/99/99, 1.05 n. mls WSW of Rocky Head, Enderby I. (2037.3-37.02'S, $\left.116^{\circ} 26.85-26.44^{\prime} \mathrm{E}\right), 17.0-19.0 \mathrm{~m}$, rake box dredge, rocks and hard corals, gorgonians, hydroids, numerous sponges, 28.07.1999; WAM C 27145 ( 1 female, $25 \mathrm{~mm}$ ), stn DA2/99/10, NE corner of Delambre I. (2023.97'S, $\left.116^{\circ} 04.82^{\prime} \mathrm{E}, 15.07 .1999\right)$; WAM C 27183 (1 male, $17 \mathrm{~mm}$ ), stn DA2/99/95, Bluff Pt, Enderby I. $\left(20^{\circ} 37.37^{\prime} \mathrm{S}, 116^{\circ} 31.69^{\prime} \mathrm{E}\right)$, 27.07.1999; WAM C 27168 (1 female, $28 \mathrm{~mm}$ ), stn DA2/99/72, Rocky Head, Enderby I. $\left(20^{\circ} 42.13\right.$ 'S, $116^{\circ} 26.22 \mathrm{E}$ ), 24.07.1999; WAM C 27170 (1 female, $26 \mathrm{~mm})$, stn DA2/99/75, NW point of Goodwyn I. (20 $\left.32.16^{\prime} \mathrm{S}, 116^{\circ} 33.70^{\prime} \mathrm{E}\right), 25.07 .1999$; WAM C 27167 (1 female, $31 \mathrm{~mm}$ ), stn DA2/99/70, Bluff Pt, Enderby I. $\left(20^{\circ} 41.45^{\prime} \mathrm{S}, 116^{\circ} 30.78^{\prime} \mathrm{E}\right), 24.07 .1999$.

\section{Remarks}

Haptosquilla corrugata was reported from the Dampier Archipelago by Ahyong (2001).

\section{Distribution}

Australia, from Gove, Northern Territory to northwestern Australia (Ahyong, 2001).

\section{Haptosquilla glyptocercus (Wood-Mason, 1875)}

Gonodactylus glyptocercus Wood-Mason, 1875: 232 [type locality: Nicobar Is, $8^{\circ} 00^{\prime} \mathrm{N}, 9^{\circ} 30^{\prime} \mathrm{E}$ ]. Stephenson, 1952: 12; 1953a: 47, 48.-Stephenson and McNeill, 1955: 253.

Protosquilla cerebralis Brooks, 1886: 22, 72, pl. 14: figs. 2, 3, pl. 16: figs. 2, 3 [type locality: Levuka, Fiji, $\left.17^{\circ} 42^{\prime} \mathrm{S}, 178^{\circ} 50^{\prime} \mathrm{E}\right]$.

Gonodactylus stoliurus.-McNeill, 1926: 317-318, fig. 2 [not G. stoliurus Müller, 1886].

Haptosquilla glyptocercus. - Ahyong, 2001: 104105, fig. 50. - Ahyong and Davie, 2002: 66

\section{Material examined}

Western Australia, Dampier Archipelago. WAM C 27598 (1 female, $12 \mathrm{~mm}$ ), stn DA2/99/16, Enderby I. $\left(20^{\circ} 35.20^{\prime} \mathrm{S}, 116^{\circ} 30.91 \mathrm{E}\right)$, from rock, 01.09.1999; WAM C 25619 (1 female, 12 mm), stn DA1/98/06, Haüy I. $\left(20^{\circ} 25.725^{\prime} \mathrm{S}, 116^{\circ} 57.580^{\prime} \mathrm{E}\right)$, low relief limestone pavement with shallow sandy gullies, few loose rocks, very little coral cover, very silty, 19.10.1998.

\section{Remarks}

Haptosquilla glyptocercus was reported as far south as Northwest Cape, Western Australia, by Ahyong (2001), although the present specimens are the first records for the Dampier Archipelago.

\section{Distribution}

Andaman Sea to Japan, Vietnam, the Philippines, Australia, New Caledonia, Guam, the Marshall Islands and Fiji (Ahyong and Erdmann, 2003).

\section{Nannosquillidae Manning, 1980}

Acanthosquilla melissae sp. nov. Figure 3

Acanthosquilla derijardi--Ahyong, 2001: 144.Ahyong and Davie, 2002: 55 [Shelburne Bay specimens only; not $A$. derijardi Manning, 1970].

\section{Material examined}

Holotype

Western Australia, Dampier Archipelago. WAM C 27142 (male, $33 \mathrm{~mm}$ ), stn DA2/99/07, C. Legendre (20²0.90'S, 116 57.04'E), 15.07.1999. 


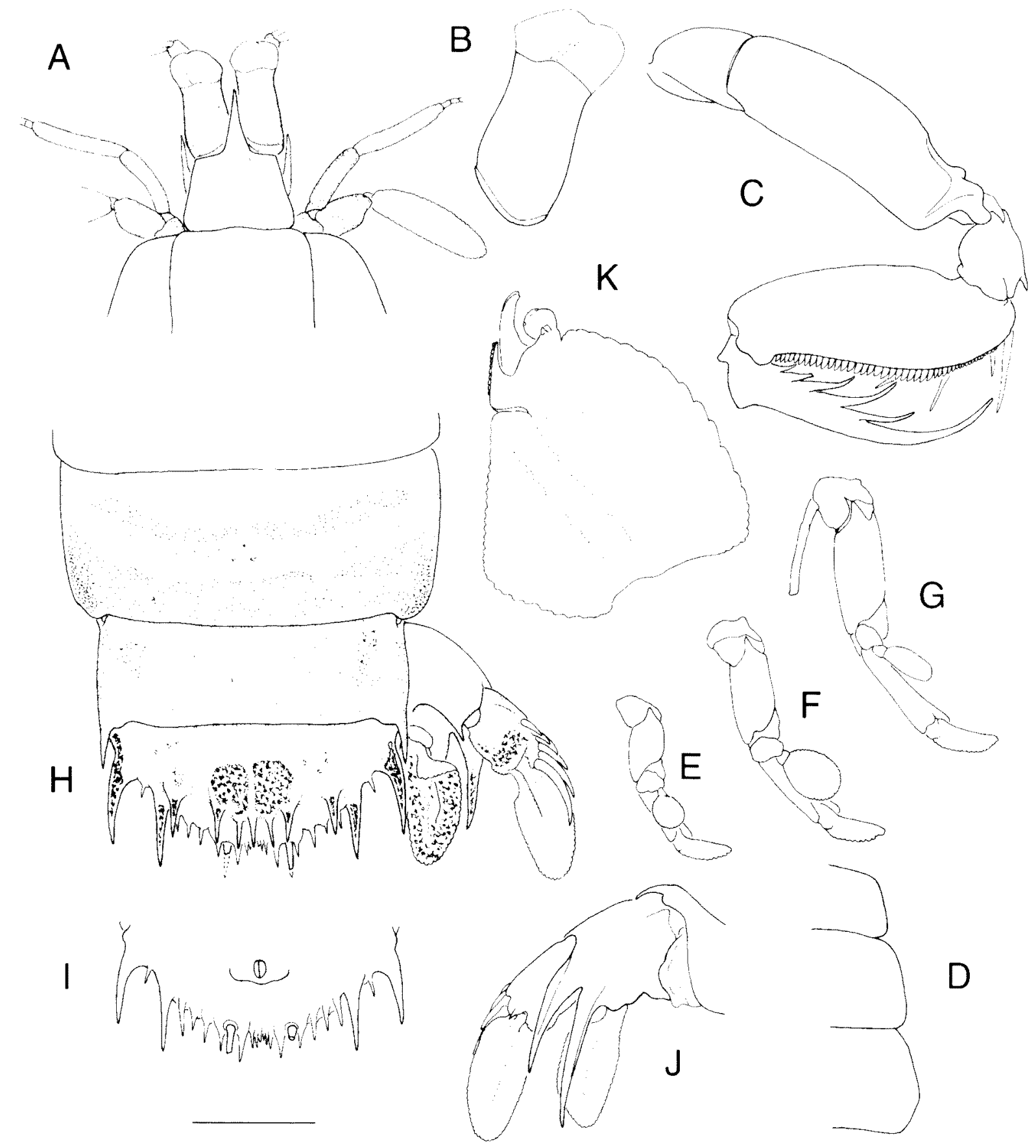

Figure 3 Acanthosquilla melissae sp. nov., male holotype TL $33 \mathrm{~mm}$ (WAM C 27142), Cape Legendre, Dampier Archipelago. A, anterior; B, right eye; $\mathbf{C}$, right raptorial claw, lateral view; D, TS6-8, right dorsal view; E, right pereopod $1 ; \mathbf{F}$, right pereopod $2 ; \mathbf{G}$, right pereopod 3; $\mathbf{H}, \mathrm{AS5}, 6$, telson and uropod; $\mathbf{I}$, telson, ventral; $J$, right uropod, ventral view; $K$, right pleopod 1 endopod, anterior view. Scale $A, C-J=2.0 \mathrm{~mm}, B, K=1.0 \mathrm{~mm}$.

\section{Paratypes}

Queensland. AM P 54463 (1 female, $46 \mathrm{~mm}$ ),

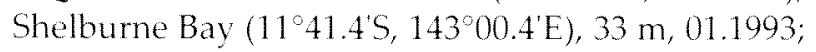
AM P 54464 (1 male, 38 mm), near Jardine I., East Is, Shelburne Bay (11²3.4'S, $\left.143^{\circ} 55.8^{\prime} \mathrm{E}\right), 12.1991$.

\section{Diagnosis}

Mesial lobe of cornea conical. Rostral plate with trapezoid proximal portion and long apical; trapezoid proximal portion half total rostral length.
Raptorial claw dactylus with 6 teeth; outer proximal margin with small proximal lobe and larger, triangular distal lobe reaching distally only as far as base of first occlusal tooth; PI 115 (male), 113 (female). Telson with 2 pairs of slender, fixed primary teeth; with 4 spiniform intermediae denticles in same plane; with 1 spiniform lateral denticle; dorsal surface with pair of mid-dorsal pits and 7 well spaced posteriorly directed spines in transverse row above marginal armature. 


\section{Description}

Eye with cornea slightly inclined laterally on stalk, mesial lobe conical; stalk elongate, extending almost to end of antennular peduncle segment 3 . Ophthalmic somite anterior margin rounded. Ocular scales rounded, separate, inclined anteriorly. A1 peduncle $0.45-0.48 \mathrm{CL}$. A2 protopod with 1 ventral papilla; A2 scale 0.34-0.40CL. Rostral plate longer than broad, with trapezoid proximal portion and long apical; trapezoid proximal portion half total rostral length; dorsal and ventral surfaces smooth. Raptorial claw dactylus with 6 teeth; penultimate tooth slightly shorter than adjacent teeth; outer proximal margin with small proximal lobe and larger, triangular distal lobe reaching distally only as far as base of first occlusal tooth. PI 115 (male), 113 (female). Mandibular palp 3segmented. Maxillipeds 1-5 each with epipod. TS67 with lateral margins truncate, rounded anterolaterally and posterolaterally. TS8 rounded; sternal keel obsolete. Endopod of male pleopod 1 with elongate tube process and short, blunt hook process. AS6 posterior margin smooth; posterolateral spine long, slender; with slender ventrolateral spine and short blunt angular lobe anterior to uropodal articulation; sternum posterior margin unarmed. Telson with 2 pairs of slender, fixed primary teeth; with 3 or 4 submedian denticles either side of midline forming inverted $\mathrm{V}$-shaped row; with 4 spiniform intermediate denticles in same plane; with 1 spiniform lateral denticle. Dorsal surface with pair of mid-dorsal pits and 7 well spaced posteriorly directed spines in transverse row above marginal armature; spine either side of posteromedian spine on slightly lower plan than other spines of transverse row. Uropodal protopod inner margin unarmed adjacent to endopod articulation; exopod proximal segment outer margin with 6 movable spines, most distal exceeding midlength of distal segment; distal margin with short ventral spine; exopod distal segment pale; endopod with median dorsal carina.

\section{Colour in alcohol}

Overall with light and dark transverse bands. Anterior carapace dark anterior and posterior transverse band, darkest at posterolateral angles. Carpus and distal quarter of merus with dark mottling. Thoracic somites with mottled transverse band anteriorly. AS1-5 each with 2 transverse bands: anterior band narrow and not reaching margins; posterior broader and reaching margins. AS6 with dark mottling. Telson dark with pale pair of dark posteromedian 'ocelli'; spines dark. Uropodal protopod with dark terminal spines. Uropodal exopod proximal segment and movable lateral spines dark; distal segment pale; endopod dark.

\section{Measurements of holotype}

TL $33 \mathrm{~mm}$, CL $6.25 \mathrm{~mm}$, A1 peduncle length 2.90 $\mathrm{mm}$, A2 scale length $2.10 \mathrm{~mm}$, raptorial claw propodus length $5.45 \mathrm{~mm}$.

\section{Etymology}

Named for Melissa Titelius, Western Australian Museum, who collected most of the specimens used in this study.

\section{Remarks}

In reporting $A$. derijardi from Australia, Ahyong (2001) noted two specimens from Shelburne Bay, Queensland, that were atypical in the size of the distal lobe on the outer proximal margin of the dactylus of the raptorial claw, and in having an unusual rostral plate in which the basal trapezoid portion was proportionately short, with a long apical spine. The distal lobe on the outer proximal margin of the dactylus of the raptorial claw in $A$. derijardi sensu stricto is massive, extending distally as far as the base of the fourth or fifth occlusal tooth whereas in the Shelburne Bay specimens, the lobe is considerably smaller, extending only to the base of the first occlusal tooth. The rostral plate in $A$. derijardi sensu stricto comprises a long proximal trapezoid portion and short rostral spine (not exceeding one-quarter of the total rostral length). In contrast, the proximal trapezoid portion of rostral plate in the Shelburne Bay specimens is only half the total rostral length, with the median spine comprising the other half. Those specimens from Shelburne Bay and the present Dampier specimen are herein referred to a new species, Acanthosquilla melissae sp. nov. Acanthosquilla melissae further differs from $A$. derijardi in having only seven spines on the upper posterior margin of the telson whereby the 'typical' five spines in other species of Acanthosquilla are present as well as a single spine on either side of (and slightly lower than) the median spine. In $A$. derijardi sensu stricto, two clusters of two or more spines are present either side of the median spine. The propodi of the raptorial claws in $A$. melissae are also proportionally longer than in $A$. derijardi with PI $113-115$ vs $122-141$ respectively, and the distal segment of the uropodal exopod is pale instead of black on the inner half.

Three nominal species are presently in the synonymy of $A$. derijardi (type locality: Grand Recif, Tuléar, Madagascar): A. multispinosa Blumstein, 1974 (type locality: Vietnam), A. manningi Makarov, 1978 (type locality: Vietnam), and A. sirindhorn Naiyanetr, 1995 (type locality: Pattani, Gulf of Thailand). Acanthosquilla sirindhorn corresponds to $A$. derijardi sensu stricto, but the two Vietnamese species appear to be valid. Acanthosquilla manningi is characterised by the presence of a field of numerous small spines 
on the upper posterior surface of the telson instead of a transverse row of spines, and $A$. multispinosa bears telson spination as in $A$. derijardi, but only a small outer distal lobe on the proximal margin of the raptorial dactylus. Acanthosquilla melissae is not referable to any of the synonyms of $A$. derijardi.

Under the account of $A$. derijardi, Ahyong (2001) also reported on a specimen from Sandakan,
Borneo, with a similar raptorial claw to $A$. melissae but with telson spination resembling $A$. derijardi sensu stricto. The Sandakan specimen is possibly referable to $A$. multispinosa. The species of the $A$. derijardi complex are presently under study.

\section{Distribution}

Shelburne Bay, Queensland, and Dampier Archipelago, Western Australia.

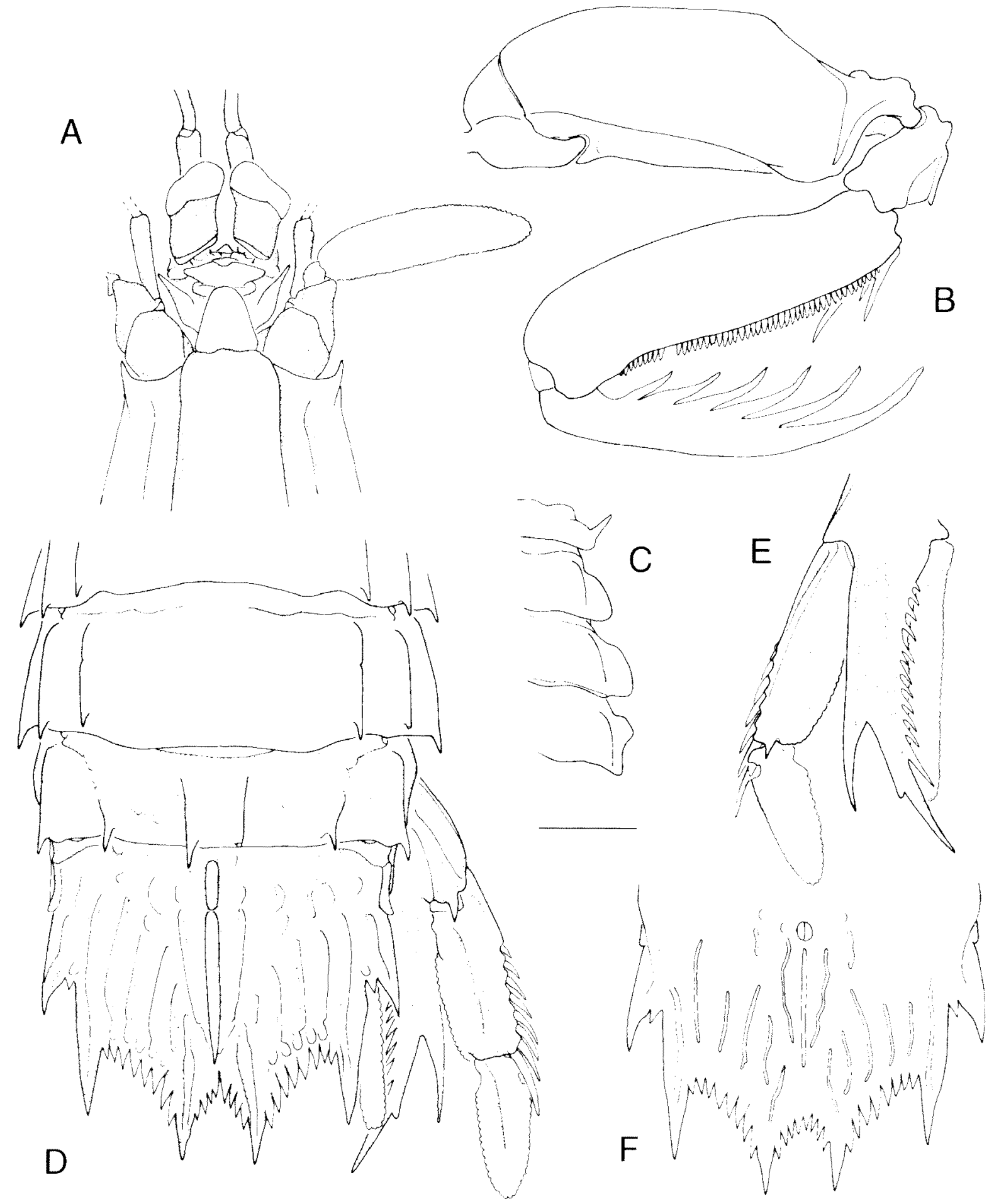

Figure 4 Anchisquilla subfasciata (Tate, 1883), male holotype TL $56 \mathrm{~mm}$ (SAM C 182), Gulf Saint Vincent, South Australia. Scale $=3 \mathrm{~mm}$. 
Squillidae Latreille, 1802

Anchisquilla subfasciata (Tate, 1883) comb. nov. Figure 4

Squilla subfasciata Tate, 1883: 52, pl. 2. figs 1a-d [type locality: Gulf St. Vincent, S Australia].

Squilla fasciata.-Hale, 1924: 496; 1927: 30, 32, fig. 21.-Stephenson, 1952: 5. - Stephenson and McNeill, 1955: 240-241, 258, 261 [not S. fasciata de Haan, 1844].

Anchisquilla fasciata.-Ahyong, 2001: 196-198, fig. 96.-Ahyong and Davie, 2002: 72-73 [not $A$. fasciata (de Haan, 1844)].

\section{Material examined}

Western Australia, Dampier Archipelago. WAM C 27151 (1 male, $54 \mathrm{~mm}$ ), DA2/99/34, 20 32.65'S (116 39.14'E, 19.07.1999); WAM C 27156 (1 female, $56 \mathrm{~mm})$, stn DA2/99/48, Rocky Head, Enderby I. (20³7.43'S, $\left.116^{\circ} 24.08^{\prime} \mathrm{E}\right), 20.07 .1999$.

\section{Remarks}

Ahyong (2001) reported Australian specimens referable to $A$. fasciata to differ from material from Thailand, Taiwan and Japan (topotypic) in having more numerous ventral telson carinae. Although the Australian specimens might be referable to a separate species, Ahyong (2001) further noted that study of specimens from intermediate localities was required. Specimens reported as $A$. fasciata from Indonesia by Holthuis (1941) in the Zoological Museum, Amsterdam, and Moosa and Cleva (1984b) in the Muséum national d'Histoire Naturelle, Paris (MNHN), were studied and proved referable to A. chani Ahyong, 2001. Specimens reported by Moosa (1991) from New Caledonia (MNHN) are also referable to $A$. chani. Material from Singapore reported by Tweedie (1934) in the Raffles Museum of Biodiversity Research, Singapore, and those reported by Moosa (1986) from the Philippines proved referable to $A$. fasciata sensu stricto. Hence, $A$. fasciata sensu stricto is not known south of the equator, and records of Anchisquilla from localities immediately adjacent to Australia are based on $A$. chani. Australian specimens consistently differ from other species of Anchisquilla and are herein regarded as distinct from $A$. fasciata sensu stricto. Squilla subfasciata Tate, 1883 (type locality Gulf St. Vincent, South Australia), presently a synonym of $A$. fasciata, is herein removed from synonymy and recognised for Australian 'A. fasciata'. Anchisquilla subfasciata is distinguished from $A$. fasciata by the presence of 4 or 5 instead of 1 or 2 carinae flanking the postanal carina. The holotype of Anchisquilla subfasciata is illustrated in Figure 2.

The present specimens constitute the first records of the species from Western Australia. Meristic counts are within the reported range (Ahyong, 2001) with 11 or 12 spines on the inner margin of the uropodal protopod, eight movable spines on the outer margin of the proximal segment of the uropodal exopod, telson denticles (submedian 4, intermediate $7-8$, lateral 1) and abdominal spination: submedian 6 , intermediate $3-6$, lateral 1 6 , marginal $1-5$.

\section{Distribution}

Australia, from Queensland north to Western Australia and Gulf Saint Vincent, South Australia.

\section{Carinosquilla carita Ahyong, 2001}

Squilla multicarinata. - Stephenson, 1962: 35, 38.

Carinosquilla carita Ahyong, 2001: 210-212, fig. 102 [type locality: $43 \mathrm{~km}$ NNE of Dampier, Western Australia]. - Ahyong and Davie, 2002: 74.

\section{Material examined}

Western Australia, Dampier Archipelago. WAM C 27178 (1 male, $29 \mathrm{~mm}$ ), stn DA2/99/88, W point of Brigadier I. $\left(20^{\circ} 26.04^{\prime} \mathrm{S}, 116^{\circ} 36.77^{\prime} \mathrm{E}\right), 26.07 .1999$; WAM C 27185 (1 female [broken], stn CL $12.3 \mathrm{~mm}$ ), DA2/99/96, Bluff Pt, Enderby I. (20³7.50'S, $\left.116^{\circ} 31.56^{\prime} \mathrm{E}\right), 27.07 .1999$.

\section{Remarks}

Carinosquilla carita was first described from the vicinity of Dampier by Ahyong (2001).

\section{Distribution}

Northwestern Australia and the Gulf of Carpentaria, Queensland (Ahyong, 2001).

\section{Clorida obtusa Ahyong, 2001}

Squilla granti.- Stephenson, 1962: 33 [not Squilla granti Stephenson, 1953b].

Clorida obtusa Ahyong, 2001: 226, fig. 110 [type locality: SE Gulf of Carpentaria, Queensland].Ahyong and Davie, 2002: 75.

\section{Material examined}

Western Australia, Dampier Archipelago. WAM C 25784 (1 male, 22 mm), DA2/99/61 (20³5.33'S, $\left.116^{\circ} 42.78^{\prime} \mathrm{E}\right), 22.07 .1999$; WAM C 27166 ( 1 male, 21 $\mathrm{mm})$, stn DA2/99/69, SE point of Goodwyn I. (20³4.34'S, $\left.116^{\circ} 34.67^{\prime} \mathrm{E}\right), 24.07 .1999$.

\section{Remarks}

Clorida obtusa was reported from northwestern Australia by Ahyong (2001), though the present specimens constitute the first records of the species from the Dampier Archipelago and a southern record for Western Australia. The specimens agree 
well with the type description and meristic counts are within the range reported: the dactyli of the raptorial claws bear four teeth, the inner margin of the uropodal protopod is armed with five spines, the outer margin of the distal uropodal exopod segment bears six movable spines and the abdominal spine formula is submedian 6 , intermediate 5-6, lateral 5-6, marginal 5

\section{Distribution}

Mackay, Queensland, the Gulf of Carpentaria, and the Northwest Shelf, Western Australia (Ahyong, 2001).

\section{Levisquilla jurichi (Makarov, 1979)}

Clorida jurichi Makarov, 1979: 40, fig. 1 [type locality: Tonkin Bay, Vietnam, 21 $13.5^{\prime} \mathrm{N}$, $\left.109^{\circ} 45.8^{\prime} \mathrm{E}\right]$.

Squilla fallax.-Stephenson and McNeill, 1955: 241, 258,261 [not Squilla fallax Bouvier, 1914].

Levisquilla jurichi--Ahyong, 2001: 271-274, fig. 133. - Ahyong and Davie, 2002: 81.

\section{Material examined}

Western Australia, Dampier Archipelago. WAM C 27161 (1 female, $25 \mathrm{~mm}$ ), stn DA2/99/61, Philip Pt, Burrup Pen. (2035.33'S, 116 42.78'E), dredge, 22.07.1999; WAM C 27181 (1 female; $18 \mathrm{~mm}$ ), stn DA2/99/93, King Pt, East Lewis 1. (2038.29'S, 116 38.39'E), 27.07.1999; WAM C 27182 (1 male, 21 $\mathrm{mm}$ ), stn DA2/99/94, King Pt, East Lewis I. $\left(20^{\circ} 38.37^{\prime} \mathrm{S}, 116^{\circ} 38.41^{\prime} \mathrm{E}\right), 27.07 .1999$; WAM C 25778 (1 female, $24 \mathrm{~mm}$ ), stn DA2/99/88 (20²6.04's, $\left.116^{\circ} 36.77^{\prime} \mathrm{E}\right), 27.07 .1999$.

\section{Remarks}

Levisquilla jurichi was recorded from northwestern Australia by Ahyong (2001) and the present specimens agree well with those already reported. Abdominal spination is as follows: submedian 6, intermediate 6, lateral 6, marginal 5 . The inner margin of the uropodal protopod bears seven spines, and the outer margin of the proximal segment of the uropodal exopod bears seven tol0 movable spines. The present specimens represent the first records from the Dampier Archipelago and the southernmost records for Western Australia.

\section{Distribution}

New Caledonia, Vietnam, the Andaman Sea and Australia (Ahyong, 2001).

\section{ACKNOWLEDGEMENTS}

Thanks are due to Diana Jones and Melissa Titelius for collecting and making the present series available for study, Charles Fransen (NNM) for the loan of the holotype of Gonodactylellus snidvongsi, Thierry Laperousaz (SAM) for the loan of the holotype of Anchisquilla subfasciata and Peter $\mathrm{Ng}$ (National University of Singapore) and Alain Crosnier (MNHN) for their generous hospitality over numerous visits to Singapore and Paris, respectively. Financial support provided by a Sydney Grammar School Fellowship is gratefully acknowledged.

\section{REFERENCES}

Ahyong, S.T. (2001). Revision of the Australian Stomatopod Crustacea. Records of the Australian Museum, Supplement 26: 1-326.

Ahyong, S.T. (2005). Coral reef mantis shrimps from the vicinity of Sodwana Bay, South Africa (Crustacea Stomatopoda). Proceedings of the Biological Society of Washington 118: 158-164.

Ahyong, S.T. and Davie, P.J.F. (2002). Hoplocarida. In Davie, P.J.F. (ed.), Crustacea: Malacostraca: Phyllocarida, Hoplocarida, Eucarida (Part 1), Zoological Catalogue of Australia Vol. 19.3A: 31-90. Melbourne: CSIRO Publishing.

Ahyong, S.T. and Erdmann, M.V. (2003). The stomatopod Crustacea of Guam. Micronesica 35-36: 315-352.

Ahyong, S.T. and Norrington, S.F. (1997). Stomatopod Crustacea in the Macleay Museum, University of Sydney. Proceedings of the Linnean Society of New South Wales 118: 97-110.

Alexander, W.B. (1916). On a stomatopod new to Australia, with a list of the Western Australian species of the order. Journal and Proceedings of the Roval Society of Western Australia 1: 8-9.

Balss, H. (1921). Results of Dr. E. Mjoberg's Swedish Expeditions to Australia 1910-13, XXIX. Stomatopoda, Macrura, Paguridea und Galatheidea. Kongliga Svenska Vetenskapsakademiens Handlingar 61: 1-24.

Blumstein, R. (1974). Stomatopod crustaceans from the Gulf of Tonkin with the description of new species. Crustaceana 26: 112-126.

Borradaile, L.A. (1900). On the Stomatopoda and Macrura brought by Dr Willey from the South Seas. In Willey, A. (ed.), Zoological Results based on the material trom New Britain, New Guinea Lovalty Islands and elsewhere, collected during the years 1895, 1896, and $1897,4: 395-428$, pls. 36-39. Cambridge University Press.

Borradaile, L.A. (1907). Stomatopoda from the western Indian Ocean. The Percy Sladen Trust Expedition to the Indian Ocean in 1905, under the leadership of J Stanley Gardiner. Transactions of the Linnean Society of London (2, Zoology) 12: 209-216

Bouvier, E.-1.. (1914), Sur la faune carcinologique de líle Maurice. Comptes Rendus Hebdomadaires des Séances de l'Academie des Sciences, Paris 159: 698704.

Brooks, W.K. (1886). Report on the Stomatopoda collected by H.M.S. Challenger during the years 1873-76. The Vovage of the H.MS. Challenger, Zoology 16:1-116. 
Dana, J.D. (1852-1855). Crustacea, Part I. United States Exploring Expedition during the vears 1838, 1839, 1840, 1841, 1842, under the command of Charles Wilkes, U.S.N. 13: 1-685 [1852]. Atlas: 1-27, pls. 1-96 [1855]. C. Sherman, Philadelphia.

Erdmann, M.V. and Manning, R.B. (1998). Preliminary descriptions of nine new stomatopod crustaceans from coral reef habitats in Indonesia and Australia. Raffles Bulletin of Zoology 46: 615-626.

Fabricius, J.C. (1781). Species Insectorum Exhibentes Eorum Differentias Specificas, Synonyma Auctorum, Loca Natalia, Metamorphosin Adiectis, Observationibus, Descriptionibus 1: vii + 552pp. Hamburgii et Kilonii.

Forskäl, P. (1775). Descriptiones Animalium, Avium, Amphibiorum, Piscium, Insectorum, Vermium $19+$ xxxii + 164 pp. Hauniae (Copenhagen).

Ghosh, H.C. (1990). Stomatopoda: Crustacea. Fauna of Lakshadweep. State Fauna Series 2: 199-212.

Giesbrecht, W. (1910). Stomatopoden, Erster Theil. Fauna und Flora des Golfes von Neapel Monographie 33: ivii, $1-239$.

Haan, W. de (1844). Crustacea. Fauna Japonica sive descriptio animalium, quae in itinere per Japoniam, jusse et auspiciis superiorum, qui summum in India Batavia imperium tenent, suscepto, annis 1823-1830 collegit, notis observationibus et adumbrationibus illustravit. P. F. de Siebold. Conjunctis studiis C.J. Temminck et $\mathrm{H}$. Schlegel pro Vertebratis atque $W$. de Haan pro Invertebratis elaborata Regis auspicus edita. 1. P. F. v. Siebold. Leiden. Lugduni-Batavorum. Decas VI + VII: pls $38,43-46,48,51-55_{r}$ I-N.

Hale, H.M. (1924). Notes on Australian Crustacea. No. 1. Records of the South Australian Museum 2: 491-502.

Hale, H.M. (1927). The Crustaceans of South Australia. Part 1. Handbook of the Flora and Fauna of South Australia, pp. 1-201. Adelaide.

Hale, H.M. (1929a). Crustacea from Princess Charlotte Bay, north Queensland. The Isopoda and Stomatopoda. Transactions of the Royal Society of South Australia 53: 33-36.

Hale, H.M. (1929b). Notes on the fauna of Dirk Hartog Island, Western Australia. No.4. Crustacea. Transactions of the Royal Society of South Australia 53: $67-70$.

Holthuis, L.B. (1941). The Stomatopoda of the Snellius Expedition. Biological Results of the Snellius Expedition XII. Temminckia 6: 241-294.

Ingle, R.W. (1971). On the nomenclature of Gonodactylus graphurus White, 1847 (nomen nudem), Miers, 1875 (Stomatopoda, Gonodactylidae). Crustaceana 21: 220221.

Kemp, S. (1913). An account of the Crustacea Stomatopoda of the Indo-Pacific region, based on the collection in the Indian Museum. Memoirs of the Indian Museum 4: 1-217.

Lanchester, W.F. (1903). Stomatopoda, with an account of the varieties of Gonodactylus chiragra. Marine Crustaceans VIII. In Gardiner, J.S. (ed.), The fauna and geography of the Maldive and Laccadive Archipelagoes: being the account of the work carried on and of the collections made by an expedition during the vears 1899 and 1900 1: 444-459.
Latreille, P.A. (1802). Histoire naturelle, générale et particuliere, des Crustacés et de's Insecte's 3: 467 pp. F. Dufart, Paris.

Makarov, R.R. (1978). New data on crustaceans of the families Lysiosquillidae and Gonodactylidae (Crustacea, Stomatopoda) from Tonkin Bay (Vietnam). Zoologischeskij zhurnal, Moscow 57: 176189. [In Russian].

Makarov, R.R. (1979). A collection of stomatopod crustaceans of the genus Clorida Eydoux \& Souleyet, 1842, from Tonkin Bay, Vietnam. Crustaceana 37: 39 56.

Man, J.G. de. (1902). Die von Herrn Professor Kükenthal im Indischen Archipel gesammelten Dekapoden und Stomatopoden. In Kükenthal, W., Ergebnisse einer zoologischen Forschungsreise in den Molukken und Borneo. Abhandlungen der Senckenbergischen naturforschenden Gesellschaft 25: 467-929.

Manning, R.B. (1966). Notes on some Australian and New Zealand stomatopod Crustacea, with an account of the species collected by the Fisheries Investigation Ship Endeavour. Records of the Australian Museum 27: 79-137.

Manning, R.B. (1970). Some stomatopod crustaceans from Tuléar, Madagascar. Bulletin du Muséum National d'Histoire Naturelle, Paris, series 2, 41: 1429-1441. [Dated 1969, published 1970].

Manning, R.B. (1980). The superfamilies, families, and genera of Recent Stomatopod Crustacea, with diagnoses of six new families. Proceedings of the Biological Society of Washington 93: 362-372.

Manning, R.B. (1981). Neotype selection for the stomatopod Squilla chiragra Fabricius, 1781. Crustaceana 40: 217-219.

Manning, R.B. (1995). Stomatopod Crustacea of Vietnam: the legacy of Raoul Serene. Crustacean Research, Special No. 4: 1-339.

Manning, R.B. and Lewinsohn, Ch. (1981). Selection of a neotype for Cancer falcatus Forskảl, 1775 (Stomatopoda). Crustaceana 41: 314-316.

Manning, R.B. and Reaka, M.L. (1981a). Gonodactylus aloha, a new stomatopod crustacean from the Hawaiian Islands. Journal of Crustacean Biology 1 : 190-200.

Manning, R.B. and Reaka, M.L. (1981b). Gonodactylus siamensis, a new stomatopod crustacean from Thailand. Proceedings of the Biological Society of Washington 94: 479-482.

Manning, R.B. and Reaka, M.L. (1982). Gonodactylus insularis, a new stomatopod crustacean from Enewetak Atoll, Pacific Ocean. Proceedings of the Biological Society of Washington 95: 347-351.

Moosa, M.K. (1986). Stomatopod Crustacea. Résultats du Campagnes MUSORSTOM I \& II Philippines, 2. Mémoires du Muséum National d'Histoire Naturelle, Paris, series A, Zoologie 133: 367-414. [Dated 1985, published 1986].

Moosa, M.K. (1989). Some stomatopods (Crustacea: Stomatopoda) from Japanese waters, with description of a new species. Bulletin of the National Science Museum, Tokyo, series A (Zoology) 15: 223-229.

Moosa, M.K. (1991). The Stomatopoda of New Caledonia 


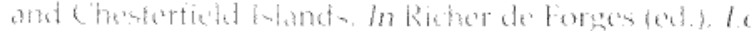

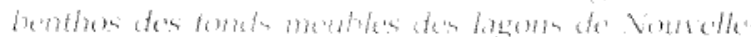

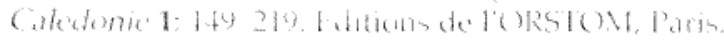

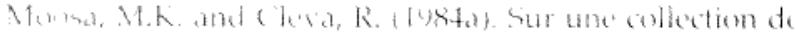
Stomatopertes (Crustacea: Hoploxaria) provenant des iles Sevchelles. Bulletin du Musem Vational

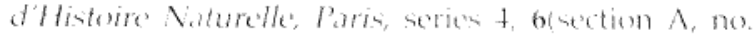
2): $421-429$

Moosd, M.K. and Cleva, R. (1984t). Stomatopont Crustacea collected by the mission Corindom $/ /$ in the Makassar Strait, Indomesia. Marme Researoh in Indonesia $24: 7,3-82$.

MeNeill, F.A. (1926). The bioluge of North-West lstet, Capricorn Group, (J) Crustacea. Australian Zoologist 4. $299-318$

MeVeill, FA (1968). Crustacea, Decapenda \& Stomatopola. Scientitio reports of the Girent Barrite Reef Expedition 1428-297: 1-98. British Museum (Natural Historv), london.

Miers, E.J. (1875). On some new or undescribed species of Crustacea from the Samoa lslands. Anmals and Magazine of Natual Histors, series 4, 16:341-34t.

Miers. F. (1880). On the Squillidat. Annals and Magarine of Vatural Histors 5: 1-30, $108-127$

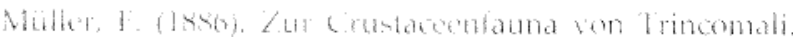

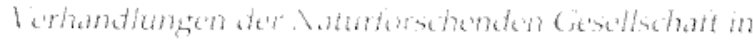
buse? 8: $470+40$

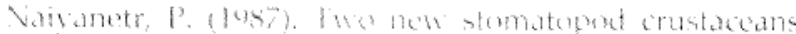
from Thathand with a here to the gernum Manmingin

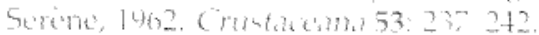

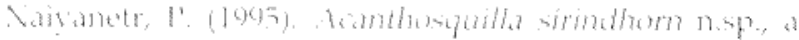

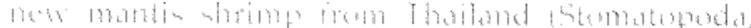

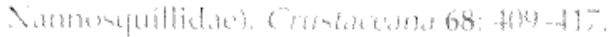

Porock, R.I. (1893). Report upon the stomatopod

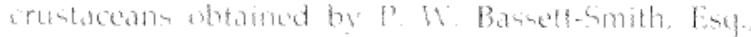

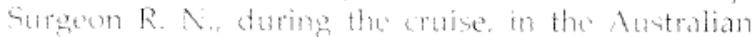
and Chmat sere of HMS. "Penguin," Commander W. U. Moure. Amnals and Magarine of Natural Ifistory, series $6,11: 473-470$

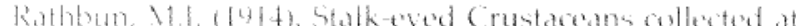

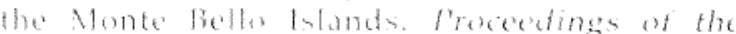

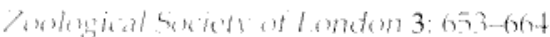

Stephenson. He (1952). Fandintic reorde from

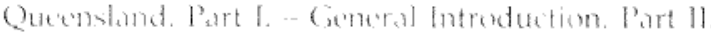
Adult Stomatopoda (Cratacea). Zookger laperes of the Liminersily of Queensland 1: 1-15.

Stephenson, W. (1953a). Notes on the Australian Stomatopeda (Crustacea) in the collections of the Queensland Museum. Memeirs of the Quensland Muse'um 13: $40-49$

Stephenson, W. (1953b). Three new Stomatopoda (Crustacea) from castern Australia. Australian foumal of Marine and Freshwater Resemeh 4:201-218

Stephenson, W. (1962). Some interesting Stomatopodamostly irom Western Australia. Lurnal of the Ronal Societs of liestern Australia 45:33-43

Stephenson, W. and McNeill, F. (1955). The Australian Stomatopoda (Crustacea) in the collections of the Australian Museum, with a check list and key to the known Australian species. Records of the Australian Museum 23: 239-265

Tate. R. (1883). Nesoriptions of some new species of Squilla from South Australia. Transactions and Procetimg of the Rowal societh of South Australia 6 . $48-53$

Tweedie, M.W.t. (1934). Notes on Stomatopoda in the Raffles Muscum. Bulletin of the Ratles Mustum Singapore $9: 33-41$.

White, A. (1847). List of the species of Crustace in the collection of the British Museum, London, viii +143 PP

Moed-Mason, I. (1875). HOn some new species of stomatopod Cruntaceal. Procededings of the Asiatic

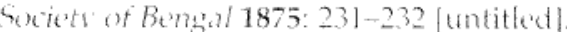

